\title{
Indigenizing the Western Concept of the University: Chinese Experience
}

\author{
Rui Yang \\ University of Hong Kong
}

\begin{abstract}
Modern universities are uniquely European in origin and characteristics. With the diffusion of the European model of the university throughout the world, the heritage of colonialism and the fact that contemporary universities are Western institutions without much linkage to their indigenous intellectual traditions are the fundamental reasons for the failure of non-Western societies to effectively establish their modern higher education systems. For China, the integration between Chinese and Western ideas of a university remains unfinished, despite many efforts to indigenize the Western concept since the $19^{\text {th }}$ century. This article examines the development and characteristics of medieval universities in Europe, and compares them with Chinese traditional higher learning institutions. Unlike most existing studies of higher education that have overwhelmingly portrayed the powerful influence of economic and political realities, this article adopts a cultural perspective to look at China's higher education development. It calls for culture to come back in the analyses of higher education development, and argues that China's universities have been able to improve their hardware considerably, while their software building lags much behind. In the present great leap forward in Chinese higher education, what is often missing is attention to cultural and institutional establishments.
\end{abstract}

Keywords The University; Medieval universities; Culture; Higher education; Traditional Chinese way of thinking; Academic freedom

\section{Introduction: Inefficacy of Universities in Non-Western Societies Including China}

Modern universities originated from Europe, spreading worldwide under conditions of imperialism and colonialism as a result of the rise of the West in modern human history. Even the societies that escaped colonial domination adopted Western models as well (Altbach 2001). To a great extent, the idea of the university is arguably the most successful Western export to the rest of the world. Elements of universities' long historical traditions directly affect global higher education and relations among academic institutions internationally. The European-origin university model has never been tolerant toward any other alternatives. The export of the university, fuelled particularly by the rise of the English language, has helped the West effectively dominate world scholarship and cultural development, leading to inefficacy of universities in nearly all non-Western societies. Western universities also influence the direction of change of higher education institutions in much of the world. Contemporary universities in non-Western societies often look to the most elite Western (usually American) counterparts for standards, policy innovations and solutions to their own development problems.

The integration between their indigenous and Western ides of a university has rarely been achieved. However, for non-Western societies to effectively build their modern higher education systems, an appropriate integration between the two is a must. This is especially the case for China, a reemerging world power with distinctive cultural and higher learning traditions. Unlike most existing comparative and international studies of higher education development that have overwhelmingly portrayed the powerful influence of economic and political realities, this article 
adopts a much-ignored cultural lens to analyze China's higher education reform and development. It traces the historical trajectory of higher education development resulted from the traditional Chinese way of thinking, and compares it with the European origin and characteristics of modern universities. It then examines the tensions in the interactions in higher education between the traditional Chinese and the imposed Western modes of thinking. It argues that without an infusion of traditional education values, China's risk losing touch with their cultural contexts in their quest for world-class status.

\section{The University: A Western Concept}

Modern universities are uniquely European in origin and characteristics (Rüegg 1992a). Their roots date back to the European history preceding the Industrial Revolution, although no one can identify with any certainty the moment in which a university came into being. The word university originated from Latin universitas which referred in general to a number of persons associated into one body, a society, company, community, guild, corporation, etc (Lewis and Short 1966). Beginning as private corporations of teachers and their pupils, the first universities were in Europe. The first degree-granting university was the University of Bologna (established in 1088). The institution that we today call the University began to take shape in Bologna at the end of the $11^{\text {th }}$ century, when masters of Grammar, Rhetoric and Logic began to devote themselves to the law. In 1158, Federico I promulgated the Constitutio Habita, in which the University was legally declared a place where research could develop independently from any other power. Other early universities, with a form of corporate/guild structure, included the University of Paris (c. 1150, later associated with the Sorbonne), the University of Oxford (1167), the University of Palencia (1208), and the University of Cambridge (1209).

During the Early Modern period (approximately late 1400s to 1800), the universities in Europe saw a tremendous amount of growth, productivity and innovative research. At the end of the Middle Ages, there were 29 universities spread throughout Europe. In the $15^{\text {th }}$ century, 28 new ones were created, with another 18 added between 1500 and 1625 (Grendler 2004). By the end of the $18^{\text {th }}$ century, there were approximately 143 universities in Europe, with the highest concentrations in the German Empire (34), Italian countries (26), France (25), and Spain (23) (Frijhoff 1996). The suitable conditions for the origination of universities did not arise until the period of time following the European Enlightenment. This timeframe is concomitant with the emergence of universal literacy initiatives, a growing and stabilized middle class, the dissipation of malign church influences over government, the early beginnings of the industrial revolution and the emergence of English as a dominant language. Prior to this, higher learning was the domain of the privileged, poorly and slowly shared among knowledge workers, and skewed by both the restrictions on thinking imposed by the governing powers and the lack of scientific knowledge (Hailman 1874).

The development of the medieval university coincided with the widespread reintroduction of Aristotle from Byzantine and Arab scholars. The European university put Aristotelian and other natural science texts at the center of its curriculum. The medieval university laid far greater emphasis on science than does its modern counterpart and descendent (Rüegg 1992b). Academic activity initially involved the scholar who, motivated by a love for knowledge, decided the parameters of a field of study and rigorously explored everything falling within them. As he or she conducted his or her research the scholar imparted the results to students who freely decided 
to follow him or her, outside of the jurisdiction of any official institution of the state or church. This process allowed society to draw upon a center of learning, applying its knowledge to practical ends. Some of them survive in some form to this day. They are the precursors of the original transformation of universities as a system of learning.

The institutions were self-regulating and determined the qualifications of their members (Colish 1997). After realizing they needed protection against local city authorities, they petitioned secular power for privileges. This later became a model. The University of Bologna began as a law school teaching the Roman law of peoples which was in demand across Europe for those defending the right of incipient nations against empire and church. Its special claim to Alma Mater Studiorum was based on its autonomy, its awarding of degrees, and other structural arrangements, making it the oldest continuously operating institution (Rüegg 2003), independent of kings, emperors or any kind of direct religious authority (Makdisi 1981). After students in Bologna were given the first privileges, another step was when Pope Alexander III in 1179 forbade masters of the church schools to take fees for granting the license to teach, and obliged them to give license to properly qualified teachers structured along three types, depending on who paid the teachers. The first type was in Bologna, where students hired and paid for the teachers. The second type was in Paris, where teachers were paid by the church. Oxford and Cambridge were predominantly supported by the crown and the state.

Such structural differences created other characteristics. In Bologna, students chose more secular studies, with law as the main subject. The students ran everything - a fact that often put teachers under great pressure and disadvantage. In Paris, teachers ran the school, and as the main subject matter was theology, control of the qualifications awarded was in the hands of an external authority - the Chancellor of the diocese. Lay students arrived in the city from many lands entering into a contract to gain this knowledge, organizing themselves into 'Learning Nations' of Hungarians, Greeks, North Africans, Arabs, Franks, Germans, Iberians etc. The students "had all the power ... and dominated the masters" (Kerr 2001, pp. 16, 145; Rüegg 2003, p. 12).

An important idea in the definition of a university is the notion of academic freedom, of which the earliest documentary evidence came from early in the life of the first university. The University of Bologna adopted an academic charter, the Constitutio Habita in 1158 or 1155 (Rüegg 2003), which guaranteed the right of a traveling scholar to unhindered passage in the interests of education, something that is claimed as the origin of "academic freedom" today (Watson 2005, p. 373). It is now a definitive characteristic for a university to ensure the freedom of inquiry by its students and academic members. This is believed to be essential to the mission of the academy, and that scholars should have freedom to teach or communicate ideas or facts, including those that are inconvenient to external political groups or to authorities, without being targeted for repression, job loss, or imprisonment.

Although academic freedom has now been recognized internationally as a definitive feature of such a university model, ${ }^{1}$ it has only been practiced genuinely in selected societies and cultures. In many others, it has proven to be a great challenge to higher education specifically and to the wider society in general. This is especially the case for many non-Western societies, where democratic cultural traditions have been historically lacking. With the diffusion of the European model of the university throughout much of the world in the $19^{\text {th }}$ century (Altbach

\footnotetext{
${ }^{1}$ For instance, 430 university rectors signed the Magna Charta Universitatum on 18 September 1988, marking the $900^{\text {th }}$ anniversary of Bologna's foundation. The number of universities signing the Magna Charta Universitatum continues to grow, drawing from all parts of the world.
} 
1998; Shils and Roberts 2004), both the heritage of colonialism and the fact that contemporary universities are Western institutions without much linkage to their indigenous intellectual traditions are fundamental reasons for their failure to establish an effective modern higher education system.

\section{Early Higher Learning Institutions in China: A Distinctive Tradition}

China's has its own long, unique higher learning traditions, which are a true portrayal of the Chinese way of thinking about human individuals, society and nature as well as the relations between them. Such different orientations of cultural thinking have led to different historical trajectories of higher education. In terms of the relationships between one and oneself, one and others, and one and nature, taking Chinese and Angelo-Saxon cultures as examples to illustrate, while the former stresses to deny self and observes the proprieties and asceticism, the latter treasures individualism; while relationships are central to the former, particular duties arising from one's particular situation in relation to others, with its theme of mutuality based on the three cardinal guides (ruler guides subject, father guides son, and husband guides wife), five constant virtues (benevolence, righteousness, propriety, wisdom and fidelity), and five orders of seniority in human relationships, the later believes that "All men are created equal;" while Chinese sages have always taught people to concentrate on human society only, their AngloSaxon counterparts have been committed to exploring the nature. Therefore, unlike the outwardlooking Western thinking, the central attention of the Chinese way of thinking has been inwardlooking, confined almost exclusively to human behaviors.

While ancient Western thinkers endeavored to explore the outside world, such as the obsession of ancient Greek philosophers with the celestial phenomena, their Chinese counterparts chose an inward-looking path. Understanding oneself as part of the world instead of as outside it, the Chinese worldview does not view humans as distinct from the world (Henkel 2006). Unlike the emphasis on the exploration of the natural world in the origin of the Western culture moving from nature to the human world, the Chinese culture was centered on humans, moving from humans to nature. A severe dichotomy between theory and practice is not present in Chinese thought. The Chinese view of the world as continual and in process. The basic difference between Western and Chinese thought is that "one constructs a model that is then projected onto the situation, which implies that the situation is momentarily 'frozen.' The other relies on the situation as on a disposition that is known to be constantly evolving" (Jullien 2004, p. 189).

Noting the different relation of humans to nature in the West and in the East as one of the salient contrasts between the two civilizations, Fairbank (1983, p. 14) wrote:

Man has been in the center of the Western stage. The rest of nature has served as neutral background or as his adversary. Thus Western religion is anthropomorphic and early Western painting anthropocentric. To see how great this gulf is we have only to compare Christianity with the relative impersonality of Buddhism, or a Sung landscape and its tiny human figures dwarfed by crags and rivers with an Italian primitive in which nature is an afterthought. 
Such a mode of thinking has had a strong impacted on the historical development of China's higher education. Firstly, it led to the unique historical roots of Chinese higher education. China's higher education had evolved according to its own logic and never deviated from its developmental path, despite external influences. By the $18^{\text {th }}$ century, China had developed a unique set of scholarly values over its 2,000 years of imperial history. Over such a long process, its higher education circles confined their dissemination of knowledge to the provincial level and persisted in disregarding knowledge about anything in the rest of the world. There was no institution in Chinese tradition that could be called a university. Instead, the imperial examination system and the Academies or Shuyuan ${ }^{2}$ were key elements of ancient Chinese higher learning (Hayhoe 1996).

During the early days of China's encounter with Western culture in the $19^{\text {th }}$ century, Chinese higher education could have taken the lead in introducing and assimilating advanced culture, science and technology to promote social and economic development. Instead, due to its exclusivity, it continued to train traditional Confucian scholars with little knowledge of the outside world. Although Western higher education models had already demonstrated their strengths, China's communication with the West was intentionally hindered. Chinese higher education within the period laid stress solely on the training of the Confucian scholars who acquired the cultivation that symbolized their social status with an encyclopedic knowledge based on Confucian values, which in practice served only the aristocracy (Yang 2002). Lacking an interest in seeking truth, traditional Chinese higher education placed its central focus on utility, in the terms of the ruling classes.

Ancient Chinese education system had been established during the Yu period (2257-2208 BC) and the imperial central academy was named Shangyang at the time. ${ }^{3}$ China's early institutions of higher learning are of considerable antiquity, predating Western higher learning institutions by centuries. The highest learning institution, the imperial central school, was called Piyong in Zhou Dynasty (1046-249 BC), ${ }^{4}$ Taixue in Han Dynasty (202-220), and Guozijian in Sui dynasty. They only resembled vaguely and superficially universities in the Western sense of the word. After unifying China, Qin dynasty banned private schooling, allowed only to study from officials, and made imperial power supreme. Emperor Wu of Han (156-87 BC) adopted an advice by Dong Zhongshu (179-104 BC) to revere only Confucianism and dismissed all the Hundred Schools of Thoughts. Dong proposed Taixue to be the best place to restore talents with its essential task to influence (Meng 1996), a place not only to train talents, but also to exert influence and select political personnel. Meanwhile, Gongsun Hong (200-121 BC), the then prime minister, suggested the government establish a system of scholars with disciples so that local communities would be positively influenced while talents were rewarded. Emperor Wu took their advices, and ordered to establish Taixue in 124 BC to host scholars and their students, with a hope that they would set a good example for the entire society.

\footnotetext{
2 The imperial examination system began to take form around 400 C.E. and reached its full institutional development in the Tang dynasty (618-907 C.E.). During the Song (960-1279 C.E.), it crystallized into patterns that were to last right up to 1911. The Academies or Shuyuan took their definitive forms in the Song dynasty, as what had been originally libraries or centers for scholarly discussion developed into academies that provided a structured learning environment separate from, yet interacting with, state institutions associated with the civil service examination system. For more information, see Ruth Hayhoe's (1996) China's Universities 1895-1995, especially pages 10-11.

${ }^{3}$ Shang means higher and Yang means school. It is no longer extant as such.

${ }^{4}$ This is, again, no longer extant as such.
} 
Taixue taught Confucianism (Ebrey 1999). Even after one year of study at Taixue with mastery of one classic, students were eligible to be chosen by the government to become officials. By so doing, the government directly controlled their political future. This was the beginning of China's strong tradition for more than two thousand years - higher education aiming at preparing would-be officials for the state. Taixue thus became a subsidiary body of the bureaucratic system (Zhang 2009). As part of the ruling system, Taixue neither could nor attempted to go beyond the imperial framework. The first nationwide government school system in China was established in 3 CE under Emperor Ping of Han, with the Taixue on the top located in the capital of Chang'an (Yuan 1994). Later, it was replaced by the Guozijian as the top level of educational institutions and as the highest organization to oversee national government school system. The development of Taixue and Guozhijian was confined to the limited range allowed by their Confucian ideologies.

Some Sinologists see the Academies as an essential element of traditional Chinese higher education, stressing their private nature and freethinking atmosphere (e.g. Hayhoe 1989). Such features, however, were not always maintained. Sitting somewhere between the private and the official, the Academies emerged in late Tang dynasty, thrived from Song to Qing dynasties. Their longstanding historical developments bore a marked brand of ideological and financial control by the government. Initially they focused more on exploring Confucianism and personal intellectual cultivation than training government officials, with operation fund mainly from private donations. Such conditions, which could have become appropriate seed and soil for Western-style universities to grow, did not last long. In Song dynasty, they became prosperous through winning recognition and financial support from government. The government extended its control via donations of books and lands. With gradual loss of independence from the government, the Academies reached their peak during Southern Song, became a major part of government education system, and trained a great deal of officials. They were integrated into the government school system from Yuan to Qing dynasties, from the appointment of lecturers to examinations, admissions and the whereabouts of the students. By Qing dynasty, their major aim had turned to be preparing for the imperial examination in the hope of winning an official rank (Zhang 2009).

Therefore, China started its higher learning system with a fundamentally different relationship between the state and educational institutions from that of European universities, leading to a strong tradition of the alliance between education and politics in Chinese history. China's early higher learning institutions were far too reliant on their relations with the ruling elites. They distinguish themselves strikingly from their counterparts in Europe: their teaching staff received government salary; they took major classical texts of the Confucian school as their curricular content; and their teaching approaches included mainly lectures and self-study with little argumentation. It is remarkable to see how such traditional ways of thinking have survived dramatic social and cultural changes in China's modern history, and how they remain deeply rooted among the Chinese people. It is precisely because of this, their impact on contemporary Chinese higher education is amazingly profound. Such markedly different cultural roots and heritages have led to continuous conflicts between the traditional Chinese and the imposed Western ideas of a university. While Chinese higher education has been fundamentally operated within the traditional mode of thinking, the Western concept of the modern university has been taken by the Chinese for its usefulness. Such a stiff mix is not always questioned thoughtfully. 


\section{Efforts to Integrate the Western Concept: Unfinished Business}

As argued above, the idea of the university is a Western export to the rest of the world. For China, the integration between Chinese and Western ideas of a university remains unfinished, despite many efforts to indigenize the Western concept since the $19^{\text {th }}$ century. It started in a piecemeal way with Matteo Ricci's arrival into China, which was the prologue to a massive play of China's embrace of Western learning. Educational ideas from the West were introduced to the then still highly Sino-centric Chinese society first by the missionaries including Ernst Faber (1839-1899), Timothy Richard (1845-1919), William Alexander Parsons Martin (1827-1916), and Young John Allen (1836-1907). While they attracted little attention from mainstream Chinese thinkers, a few open-mined thinkers such as Wei Yuan and Xu Guangqi began to explore Western universities. Based on those in their home countries, some of the missionaries established universities in China (Jin 2000). Many others were heavily involved in the growth of Chinese modern universities. Charles Daniel Tenney, for example, was invite by Sheng Xuanhuai to be the Dean of Studies at Peiyang University and remained at the post for 11 years.

The Opium Wars forced more Chinese to open their eye. China's first embassy, Guo Songtao, was sent to the UK in 1876. He observed British universities carefully during his two years stay there. While most in the Qing government, including his own deputy in the UK, still held the "foreign craft" in contempt, Guo developed far better understanding of the values underlying British universities and the vital role played by universities in nation-building (Fan 2002). Echoing Guo was Yan Fu who saw more fundamental roles of education. He correctly pointed out that scientific rationality was the essence of Western leaning, and called for a scientific spirit among the Chinese people. Such an understanding exerted wide and profound influence on Chinese intellectuals.

Efforts to indigenize the Western university model succeeded somewhat at various levels. At the individual level, Cai Yuanpei deserved the highest tribute. Believing that education was the only way to rejuvenate China (Cai 1997), he went to Germany in 1907 to obtain actual experience and enrolled at Leipzig University where he took courses in philosophy, aesthetics, anthropology and experimental psychology. He studied German universities from their historical and philosophical roots to daily operation, combining theoretical inquiry with personal experience and on-the-spot observation. He introduced German classical ideas of a university into China (Mora 2001), and was able to make courageous experiment when he was appointed Minister of Education by the government in 1911 and Chancellor of Peking University in 1917. He transformed the university from an official institution of the Qing dynasty, already rotten in thought and action despite the fact it had been established only recently, into a modern institution. His success as a leader of a university was unprecedented and still without parallel nearly a century later. Dewy even set a higher value on his remarkable leadership in comparison with the presidents of the most prestigious American and British universities (Feng 1992). Cai's attempt was to combine the Chinese educational spirit with Western systems. He was joined by a few like-minded others including his successor Hu Shi, Mei Yiqi (president of Tsinghua University) and $\mathrm{Zu}$ Kezheng (president of Zhejiang University). However, few could achieve as highly.

Institutional success of this period of extreme hardships is the National Southwestern Associated University in Kunming, an amalgamation of three major national universities: Tsinghua, Peking and Nankai during the Second Sino-Japanese War. Over the eight years of war (1937-1945), the institution became known nationwide for having and producing many of China's most prominent academics, scholars, scientists and intellectuals. In addition to struggling 
for physical survival, its staff and students spent the war years striving to uphold a model of higher education in which modern universities, based in large part on the American model, sought to preserve liberal education, political autonomy, and academic freedom. After the war ended, the majority of the university community returned to their north China campuses in Beijing and Tianjin. Successful in the face of wartime privations, enemy air raids, and political pressure from the ruling party, the University’s ideal had been largely replaced with a highly politicized and technocratic model borrowed from the Soviet Union by the early 1950s. Academic freedom and world-class qualities in teaching and research soon belonged to the past.

At the system level, the period of 1911 to 1927 saw the first real effort to establish a "university" in the sense of the defining values of autonomy and academic freedom. Within the period, a tremendous range of new higher education institutions also developed and flourished. Different strands of China's own evolving traditions linked up with various foreign influences, with America replacing Japan as the most favored source of influence. Hayhoe (1996) rightly and sharply points out that the lack of central government provided Chinese higher education with the possibility of vigorous experimentation. It is also important to add that many Chinese scholars who returned from Western countries and Japan played a critical role in the development of higher education. Educational thought gradually matured, with eclectic foreign influences, particularly from America and Europe.

What needs to be emphasized is that it is not purely accidental that these relative successes at all three levels were only achieved when the Chinese nation was plunged into an abyss of suffering. Although unfortunate and ironic, it shows the extremely limited room allowed by strong Chinese traditions for higher education institutions to maneuver. While the successes at system and institutional levels were achieved when the state had little time and energy for them, Cai's success was largely due to his most senior status within the ruling party as one of the founders. His successful stories could hardly be replicated by others. Instead of creating a magic mechanism to delink university operation from the government, his achievement was made possible because of his personal relationship with the highest officials. Within a decade after his departure from Peking University, his influence weakened. The conflict between traditional Chinese emphasis on political pragmatism and the classical persistence in ontological significance of knowledge from the West was never blended well. The ideal to integrate Chinese and Western ideas was never materialized.

The situation continues. As for where to get policy innovations, contemporary university reforms in China are a combination of externally imposed standards forcing China to adopt international (usually Western, and often American) modes of education and administration, as well as voluntary and even enthusiastically acceptance of foreign standards of academic excellence. Most of the international models for reform used by Chinese universities are based on the American experience. An institutional example is Peking University, whose personnel reform has been based almost entirely on the perceived US experience (Yang 2009). The grafting of American policies onto Chinese university structure is not always built on sound understanding of the cultural differences involved (Mohrman 2008). In this sense, Gan's (2005) accusation of Peking University reformer Zhang Weiying's shortage of US higher education experience on the one hand, and his almost entirely reliance on the American experience on the other, is relevant. Other reformers at Peking University act in a similar way. Min (2004) cites exclusively Harvard and Stanford Universities to legitimize their policy moves and states repeatedly that American research universities are the best in the world. Such wholesale adoption 
of US plans may not be totally appropriate for a country with a very different history and cultural traditions (Mohrman 2005).

Another example is China's contemporary higher education policy, which demonstrates Deng Xiaoping's strategy of “groping for stones to cross the river," where ideologies are chosen to be put aside and traditional differences in educational values are shelved. What is stressed most is the possible educational contribution to economic growth. By the 1980s, China had incorporated a series of measures from foreign experiences including decentralization and market mechanism, without exploring the institutional support for and the ideological foundations of these approaches, which had been implemented in selected Anglo-Saxon societies. While the structure of Chinese education remained largely based on the former Soviet model, the reforms were clearly American oriented (Hayhoe 1989). Little serious work was done to explore whether American branches could be effectively grafted on a Soviet tree planted in a Chinese garden (Pepper 1990). China's emphatic determination to separate the advanced knowledge of Western capitalist countries from what were still perceived as "decadent ideas" and a "bourgeois way of life" had overtones of the formula devised in its early modernization efforts: "Chinese learning as the substance, Western techniques for their usefulness” (Ayers 1971). The disaggregation of Western culture into positive and negative elements was arbitrary. There had been no real equilibrium between Chinese and Western learning, a basic premise of China's successful integration into the world community.

Since the 1990s, China's higher education policies have aimed at both qualitative and quantitative developments, including the Program for Education Reform and Development in China (1993), the Education Act of the People's Republic of China (1995), the 211 Project (initiated in 1995) and the 985 Project (initiated in 1998), and the dramatic expansion starting from 1999. More recent is the "largely imitative rather than creative" quest for world-class universities (Mohrman 2005). The latest policy initiative is the Medium and Long-Term Education Reform and Development Plan (2010-2020) approved by the State Council in May 2010, which is expected to demonstrate the vision and determination of the Chinese leadership, considering that it is China's educational blueprint for the next ten years. What it lacks, like its predecessors, is exactly what is required for a blueprint especially for a re-emerging China. The Plan continues to demonstrate prioritized economic considerations in educational policy-making. Economic development is the reference point in every part of the initiative, leaving knotty issues of culture and values aside. It fails to make cultural preparation for China's more well-round future global roles.

\section{Conclusion: Back to Culture}

In Chinese history, there have only been two cases in which foreign influences brought to Chinese culture had such a great impact that the host culture was fundamentally changed. One was the introduction of Buddhism into China, which took over a millennium for the Chinese to receive Buddhism to respond to its challenges and to reshape Chinese mentalities at both the intellectual and the popular levels. The other, the intrusion of Western culture into China since the $19^{\text {th }}$ century, is still on-going, as the result of a large-scale Western expansion. The magnitude is far greater than in the first case, at a time when the vitality of Chinese culture was just about to exhaust while the momentum of Western culture was at its zenith (Hsu 2001). The 
process is far from completed, and pain is felt on a constant and regular basis. China's contemporary higher education development is part of this much wider cultural process.

Throughout the modern era, Western and Chinese learning have contended for hegemony. Education has always been a key aspect of reform efforts (Bastid 1988). China's experience has showed that the transfer of Western practice conflicts with the Chinese traditions. Modern universities are a foreign transplant to China. Indigenous Chinese highest learning institutions only shared superficial resemblance with the medieval universities in Europe. The central purpose of China's modern higher education has been to combine Chinese and Western elements. This would be a combination that brings together aspects of the Chinese and Western philosophical heritages. It has never been achieved. The emphasis has always been on use, with corresponding ignorance of body. The development of Chinese modern universities has been confronted with the absence of both classical and modern ideas of a university. While Chinese longstanding traditions never attempted to seek the ontological significance of knowledge, practical demands, consciously and unconsciously, have always been the highest priority.

At certain stage, China's strategies have been effective. Chinese universities beat India's in almost every international ranking. According to the latest Academic Ranking of World Universities (ARWU) (2012), China has 4 in the top 200; 3 in the top 300, 7 in the top 400, and 14 others in the top 500, featuring 28 times in the top 500, while India only once. The promise, however, is doomed to be limited (Altbach 2010). China's universities have been able to improve their hardware considerably, while, as is always the case in China, the software building takes much longer. China thus has a considerable distance to go before its aspirations to create truly world-class universities are fulfilled. In the present great leap forward in Chinese higher education, what has often been missing is attention to cultural and institutional establishments (Yang 2011). Simply buying state-of-the-art laboratory equipments will not guarantee the kind of intellectual atmosphere that has developed over centuries on European and American campuses. In a context of a growing Chinese power, a truly Chinese world-class higher education system plays a significant role in the preparation for China's global roles. This requires a mixture of vision and boldness.

Essentially, this is part of a much more general process of seeking an alternative to Western globalization. An appropriate integration between indigenous and Western ideas of the university demands enormous economic, cultural and human resources. Without successfully integrating the indigenous and the Western, the best one can do is like Japan which could have achieved much higher based on its Confucian cultural heritage and its position as world's second largest economy for decades. What Japanese universities have achieved is typical and indeed the best in this scenario: learning the useful part while leaving the ideological aside. One telling indicator of such unsuccessfulness is the highly successful University of Tokyo which is world's $20^{\text {th }}$ by the ARWU 2012, the best among non-Western institutions. Compared with some of its Western peers of similar age, such as Stanford University and the University of Chicago, the University of Tokyo has had far less social and cultural influence, despite its remarkable performances in scientific and technological research. What the previous world's second largest economic power has not been able to achieve is now left to the current world's second largest economic power. Whether or not it can deliver remains to be seen. 


\section{References}

Academic Ranking of World Universities (ARWU), Shanghai Jiao Tong University (2012). Academic ranking of world universities. http://www.arwu.org/ARWU2010.jsp. Accessed 16 August 2012.

Altbach, P. (1998). Comparative higher education: Knowledge, the university, and development. Hong Kong: Comparative Education Research Center, University of Hong Kong.

Altbach, P. (2001). The American academic model in comparative perspective. In P. Altbach, P. Gumport \& B. Johnstone (Eds.), In defense of American higher education (pp. 11-37). Baltimore, MD: Johns Hopkins University Press.

Altbach, P. (2010). Enter the dragons? Not so fast. Times Higher Education, 17 June, 39.

Ayers, W. (1971). Chang Chih-tung and educational reform in China. Cambridge, MA: Harvard University Press.

Bastid, M. (1988). Educational reform in early twentieth-century China. Ann Arbor, MI: Center for Chinese Studies, University of Michigan.

Cai, J. (1997). Cai Yuanpei and modern China. Shanghai: Shanghai Science Press. (In Chinese)

Colish, M. (1997). Medieval foundations of the Western intellectual tradition, 400-1400. New Haven: Yale University Prress.

Ebrey, P. (1999). The Cambridge illustrated history of China. Cambridge: Cambridge University Press.

Fairbank, J. (1983). The United States and China. Cambridge, MA: Harvard University Press.

Fan, J. (2002). Lonely forerunner: A biography of Guo Songtao. Beijing: People's Literature Publishing House. (In Chinese)

Feng, Y. (1992). A short history of Chinese philosophy. Hong Kong: Pacific Ocean Publishing Co. (In Chinese)

Frijhoff, W. (1996). Patterns. In H. de Ridder-Symoens \& W. Rüegg (Eds.), A history of the university in Europe. Vol. 2: Universities in early modern Europe (1500-1800) (pp. 43-110). Cambridge: Cambridge University Press.

Gan, Y. (2005). The Beida reform follows the example of "peach pickers” but should spend more time "planting peach trees'. Chinese Education and Society, 38(1), 75-79.

Grendler, P. (2004). The universities of the Renaissance and reformation. Renaissance Quarterly, 57, 1-3.

Hailman, W. (1874). Twelve lectures on the history of pedagogy: Delivered before the Cincinnati Teachers' Association. New York: Van Antwerp, Bragg and Co.

Hayhoe, R. (1989). China's universities and Western academic models. Higher Education, 18(1), 49-85.

Hayhoe, R. (1996). China's universities 1895-1995: A century of cultural conflict. New York: Garland.

Henkel, J.E. (2006). Book review of A treatise on efficacy: Between Western and Chinese thinking by François Jullien (Honolulu: University of Hawaii Press, 2004), Philosophy East \& West, 56(2), 347-351.

Hsu, C. (2001). Chinese encounters with other civilizations. International Sociology 16(3), 438454.

Jin, Y. (2000). Studies of modern Chinese universities. Beijing: Central Party Literature Press. (In Chinese)

Jullien, F. (2004). A treatise on efficacy: Between Western and Chinese thinking. Honolulu: University of Hawaii Press. 
Kerr, C. (2001), The uses of the university. Cambridge, MA: Harvard University Press.

Lewis, C. \& Short, C. (1966). A Latin dictionary. Oxford: Clarendon Press.

Makdisi, G. (1981), Rise of colleges: Institutions of learning in Islam and the West. Edinburgh: Edinburgh University Press.

Meng, X. (Ed.), (1996). Collections of ancient Chinese works on education. Beijing: People's Education Press. (In Chinese)

Min, W. (2004). Secretary Min Weifang's face-to-face interview with Chinese central television on the subject of Beijing University's personnel reform. Chinese Education and Society, 37(6), 38-47.

Mohrman, K. (2005). Sino-American educational exchange and the drive to create world-class universities. In C. Li (Ed.), Bridging minds across the Pacific (pp. 219-235). Lanham: Lexington Books.

Mohrman, K. (2008). The emerging global model with Chinese characteristics. Higher Education Policy, 21, 29-48.

Mora, José-Ginés (2001). Governance and management in the New University. Tertiary Education and Management, 7, 95-110.

Pepper, S. (1990). China's education reform in the 1980s: Policies, issues, and historical perspectives. Institute of East Asian Studies, University of California, Berkeley.

Rüegg, W. (1992a). Foreword: The University as a European institution. In W. Rüegg (Ed.), A history of the University in Europe. Vol. 1: Universities in the Middle Ages (pp. xix-xx). Cambridge: Cambridge University Press.

Rüegg, W. (1992b). Epilogue: The rise of humanism. In W. Rüegg (Ed.), A history of the university in Europe. Vol. 1: Universities in the Middle Ages (pp. 442-468). Cambridge: Cambridge University Press.

Rüegg, W. (2003), Mythologies and historiogaphy of the beginnings. In W. Rüegg (Ed.), A history of the university in Europe. Vol. 1: Universities in the Middle Ages (pp. 4-34). Cambridge: Cambridge University Press.

Shils, E. \& Roberts, J. (2004). The diffusion of European models outside Europe. In W. Rüegg (Ed.), A History of the University in Europe. Vol. III: Universities in the nineteenth and early twentieth centuries (1800-1945) (pp. 163-230). Cambridge: Cambridge University Press.

Watson, P. (2005). Ideas. London: Weidenfeld \& Nicolson.

Yang, R. (2002). Third delight: The internationalization of higher education in China. New York: Routledge.

Yang, R. (2009). Enter the dragon: China's higher education returns to the world community, In J. Smart \& W. Tierney (Eds.), Higher education: Handbook of theory and practice (pp.431467). Dordrecht: Springer.

Yang, R. (2011). Self and the other in the Confucian cultural context: Implications of China's higher education development for comparative studies. International Review of Education 57(3-4), 337-355.

Yuan, Z. (1994). Local government schools in Sung China: A reassessment. History of Education Quarterly 34(2), 193-213.

Zhang, Y. (2009). Western ideas of a university in China: Introduction and impact. Hangzhou: Zhejiang University Press. (In Chinese) 